27. Kochling S, den Dunnen TJ, Dworniczak B, Horst J. Two polymorphic dinucleotide repeats in intron 44 of the dystrophin gene. Hum Genet 1995;95:475-477.

28. Comi GP, Ciafaloni E, DeSilva HA, et al. A G ${ }^{+1} \rightarrow$ A transversion at the $5^{\prime}$ splice site of intron 69 of the dystrophin gene causing the absence of peripheral nerve Dp116 and severe clinical involvement in a DMD patient. Hum Mol Genet 1995; 4:2171-2174.

29. Nicholson LV, Johnson MA, Bushby KMD, et al. Integrated study of 100 patients with Xp21 linked muscular dystrophy using clinical, genetic, immunochemical, and histopathological data. Part 1: Trends across the clinical groups. J Med Genet 1993;30:728-736.

30. Passos Bueno MR, Bakker E, Kneppers ALJ, et al. Different mosaicism frequencies for proximal and distal Duchenne muscular dystrophy (DMD) mutations indicate difference in etiology and recurrence risk. Am J Hum Genet 1992;51:11501155 .

31. Leibowitz D, Dubowitz V. Intellect and behaviour in Duchenne muscular dystrophy. Dev Med Child Neurol 1981;23: 577-590.

32. Dorman C, DesNoyers Hurley A, D’Avignon J. Language and learning disorders of older boys with Duchenne muscular dystrophy. Dev Med Child Neurol 1988;30:316-327.

33. Billard C, Gillet P, Barthez M, Hommet C, Bertrand P. Reading ability and processing in Duchenne muscular dystrophy and spinal muscular atrophy. Dev Med Child Neurol 1998;40: $12-20$.

34. Lenk U, Hanke R, Thiele H, Speer A. Point mutations at the carboxy terminus of the human dystrophin gene: implications for an association with mental retardation in DMD patients. Hum Mol Genet 1993;2:1877-1881.

35. Rapaport D, Passos-Bueno MR, Brandao L, Love D, Vainzof M, Zatz M. Apparent association of mental retardation and specific patterns of deletions screened with probes cf56a and cf23a in Duchenne muscular dystrophy. Am J Med Genet 1991;39:437-441.

36. Hinton VJ, Nereo NE, Stern Y, DeVivo DC. Boys with Duchenne muscular dystrophy have impaired auditory comprehension of complex verbal material. Neurology 1997;48(suppl 2): P05.002. Abstract.

37. Sicinski P, Geng Y, Ryder-Cook AS, Barnard EA, Darlison MG, Barnard PJ. The molecular basis of muscular dystrophy in the mdx mice: a point mutation. Science 1989;244:15781580 .

38. Vaillend C, Ungerer A. Behavioral characterization of mdx3cv mice deficient in C-terminal dystrophins. Neuromuscul Disord 1999;9:296-304.

39. Vaillend C, Billard JM, Claudepr T, Rendon A, Dutar P, Ungerer A. Spatial discrimination learning and CA1 hippocampal synaptic plasticity in $\mathrm{mdx}$ and $\mathrm{mdx} 3 \mathrm{cv}$ mice lacking dystrophin gene products. Neuroscience 1998;86:53-66.

\title{
Neuro/mages
}
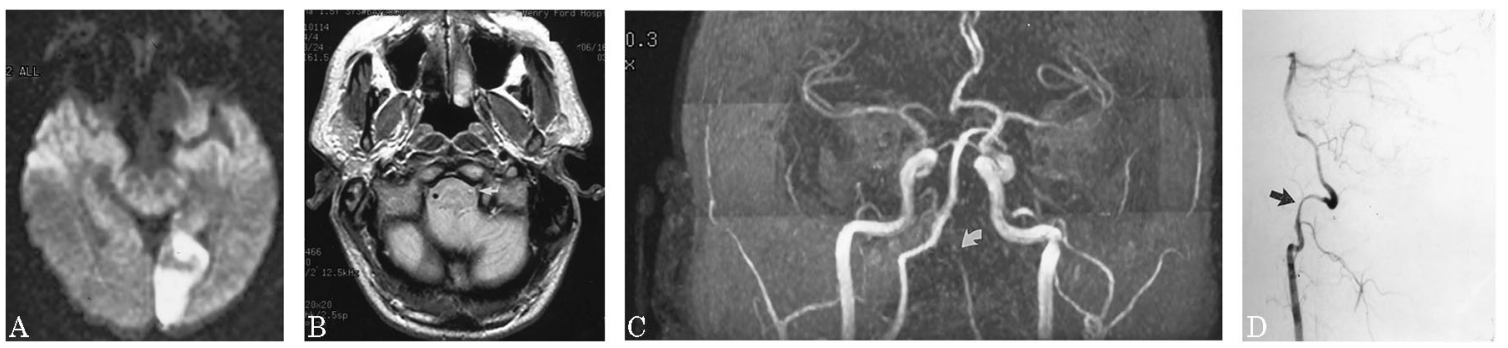

Figure. (A) Diffusion-weighted MRI revealed an acute left occipital lobe infarct. (B) Proton density-weighted sequence showed absence of the normal flow void in the left vertebral artery (arrow). (C) MR angiography showed absence of the distal portion of the left vertebral artery (arrow). (D) Cerebral angiography revealed an area of stenosis of the left vertebral artery, in the C2-C1 segment (arrow).

\section{Amusement park stroke}

Jorge G. Burneo, MD, Rhonna Shatz, DO, Nikolaos I.H. Papamitsakis, MD, Panayiotis D. Mitsias, MD,

Detroit, MI

A previously healthy 30 -year-old man presented to the emergency room 2 days after a roller-coaster ride complaining of diplopia and cervical pain. There was no trauma during the roller-coaster ride. His medical history was unremarkable. Examination revealed no meningeal signs and a right homonymous hemianopsia.

Diffusion-weighted MRI revealed an acute left occipital lobe infarct (figure, A). Proton density-weighted sequence showed absence of the normal flow void in the left vertebral artery (arrow in figure, B). MR angiography showed absence of the distal portion of the left vertebral artery (arrow in figure, C). Cerebral angiography revealed an area of stenosis of the left vertebral artery, in the C2-C1 segment (arrow in figure, D). The imaging studies supported the clinical diagnosis of left vertebral artery dissection (VAD) and left occipital infarction. The patient was placed on anticoagulation for 6 months and subsequently on aspirin. He has no recurrent cerebral ischemia after 10 months of follow-up.

Neck hyperextension almost always occurs during roller-coaster rides. VAD can result from rotational forces applied to the third segment of the artery at the C2 and C1 vertebral levels. The dissection leads to stenosis of the true lumen and disruption of the epithelium. The resulting slow flow, turbulence, or endothelial irregularity can lead to local thrombus formation and subsequent artery-to-artery embolism, usually to the posterior cerebral artery. VAD should be considered in the differential diagnosis of vertebrobasilar territory ischemia in young adults, even when there is no preceding trauma. Stroke occurring after a roller-coaster ride should be considered due to extracranial vessel dissection until proven otherwise. This case joins the series of neurologic injuries reported in the literature due to roller-coaster rides. ${ }^{1,2}$

\footnotetext{
1. Biousse V, Chabriat H, Amarenco P, Bousser MG. Roller-coaster-induced vertebral artery dissection. Lancet 1995; 346(8977):767.

2. Fukutake T, Mine S, Yamakami I, Yamaura A, Hattori T. Roller-coaster headache and subdural hematoma. Neurology 2000;54:264.
} 


\section{Neurology}

Amusement park stroke

Neurology 2000;55;564

DOI 10.1212/WNL.55.4.564

This information is current as of August 22, 2000

\section{Updated Information \&} Services

\section{Citations}

Permissions \& Licensing

Reprints including high resolution figures, can be found at: http://n.neurology.org/content/55/4/564.full

This article has been cited by 1 HighWire-hosted articles: http://n.neurology.org/content/55/4/564.full\#\#otherarticles

Information about reproducing this article in parts (figures,tables) or in its entirety can be found online at:

http://www.neurology.org/about/about_the_journal\#permissions

Information about ordering reprints can be found online:

http://n.neurology.org/subscribers/advertise

Neurology ${ }^{\circledR}$ is the official journal of the American Academy of Neurology. Published continuously since 1951, it is now a weekly with 48 issues per year. Copyright . All rights reserved. Print ISSN: 0028-3878. Online ISSN: 1526-632X.

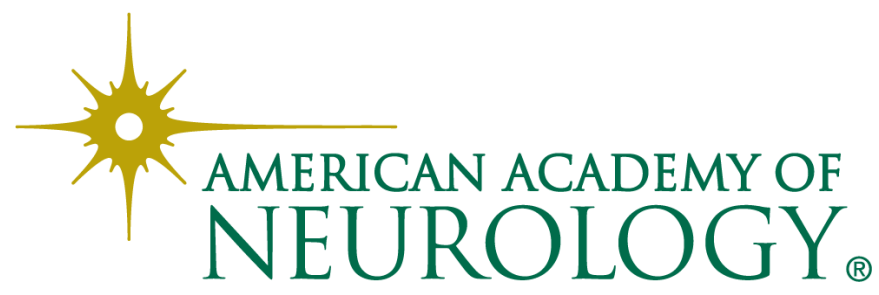

